\title{
THE IMPLEMENTATION OF MULTIMEDIA-BASED APPROACH TO PROMOTE SCHOOL DROPOUTS' LEARNING MOTIVATION IN BILIK PINTAR LEARNING FACILITY IN JAKARTA
}

\author{
Eugenius Kau Suni, Wawan Ridwan, Edwar Juanda \\ Universitas Mercu Buana Jakarta, Indonesia.
}

\begin{abstract}
The school dropout rate in Jakarta remains high, according to the Jakarta Governor, Anies Baswedan. 116.000 students aged 16 to 18 , who are school bound, discontinue or stop their education due to various reason - mostly due to socio-economic factors. Some of them decided to be street buskers and trash scavenger. There are 72 school dropouts enrolled to an emergency learning facility located in a cemetery complex owned by the local government. The location is also serving a temporary landfill in TPU Menteng Atas, Setiabudi, Jakarta. The aptly named Bilik Pintar (Bilpin) or smart chamber is currently facilitating 12 High School-aged students, 17 Junior High School-aged students, 21 Elementary-aged students and 24 Kindergarten/Preschool-aged students. The learning media and its materials are apparently limited. This situation leads to learners' reluctance to study or attend classes. We found out that the implementation of multimedia-based learning in Bilpin is proven to promote the learners' motivation and, and to some extend inspire them to go back to school. This learning approach basically makes use of multimedia, namely, computer, office software, website creation tools, coding tool, game making tool, graphic design and video editing software. After the first 5 months of the implementation, $98 \%$ of the program participants are willing to learn further and develop their passion to learning. $11,4 \%$ of them decided to go back to school and $34,3 \%$ of them reconsidered going back to school.
\end{abstract}

Keywords: Bilik Pintar Learning Facility, Street Hustlers, Promoting Students' learning motivation and Multimedia Learning

\section{INTRODUCTION}

DKI Jakarta has been a central province as the capital city of Indonesia. This special status doesn't make Jakarta immune to social problems - which urgently requires special concern from the local government. Wealth gap is one of the apparent causes. It's easy to identify this problem by comparing the high-class housing complex and those living on communal slump area. The data from the National Statistics Bureau shows that the Gini index is at $0,41 \%$, around 389,690 are classified as financially vulnerable. They make up $3,77 \%$ of the total population in the province. 1] Another intriguing phenomenon is the school dropout rate. It's considered high at a total whooping 5,358 children of a school age dropped out of school in 2017 alone. 51,21\% (2.690 students) are from the Vocational Education Program (better known SMK), respectively 20,15\% (1.080 students) dropped out of junior high school level, meanwhile for elementary level is at $18,32 \%$ with the total number of 982 students. [2].

Table 1. The Dropout Rate in The Special Region of Jakarta in 2016/2017 [2]

\begin{tabular}{|c|c|r|c|}
\hline No & Level & $\begin{array}{c}\text { The number of school } \\
\text { dropouts }\end{array}$ & $\begin{array}{c}\text { Percentage of the total } \\
\text { dropouts }\end{array}$ \\
\hline 1 & Elementary School & 982 students & $18,32 \%$ \\
\hline 2 & Junior High School & 1.080 students & $20,15 \%$ \\
\hline 3 & Senior High School & 606 students & $11,31 \%$ \\
\hline 4 & Vocational High School & $2.690 \quad$ students & $50,21 \%$ \\
\hline \multicolumn{2}{|r|}{ Total } & $\mathbf{5 . 3 5 8}$ students & \\
\hline
\end{tabular}

The Bilik Pintar Learning Facility in Kampung Pemulung - which can be literally translated into the kampong of trash scavenger, is located within the public cemetery in Menteng Pulo, Kelurahan Mentang Atas, Setiabudi District, Jakarta Selatan. The establishment of such facility is a part of the effort to address the existing problem. The facility has been conducting a free learning program on 8-meter-square room. This emergency learning shelter is close to a temporary landfill. This slump neighbourhood has been a housing complex for trash scavengers, homeless and street buskers. The learning facility welcomes their children, especially those who still have the willingness to learn and to get a brighter future. Following is the statistic of the students in the facility. 
Table 2. School-Aged Children in 2018

\begin{tabular}{|c|l|l|}
\hline NO & \multicolumn{1}{|c|}{ AGE GROUP } & \multicolumn{1}{c|}{ Number } \\
\hline 1 & SMA (Senior High School) & 12 students \\
\hline 2 & SMP (Junior High School) & 17 students \\
\hline 3 & SD (Elementary Level) & 21 students \\
\hline 4 & TK/PAUD (Kindergarten and Preschool Level) & 24 students \\
\hline \multicolumn{2}{|c|}{ TOTAL NUMBER } & $\mathbf{7 4}$ students \\
\hline
\end{tabular}

Most of the students are school dropouts. Moreover, the teachers are volunteers. This makes the teachers' availability becoming fluctuating and inconsistent. The centre has 4 'permanent tutors', namely, Pak Bowo, Ibu Wati, Ibu Mia, \& Pak Narto. If the tutors can't teach the students, they must learn on their own.

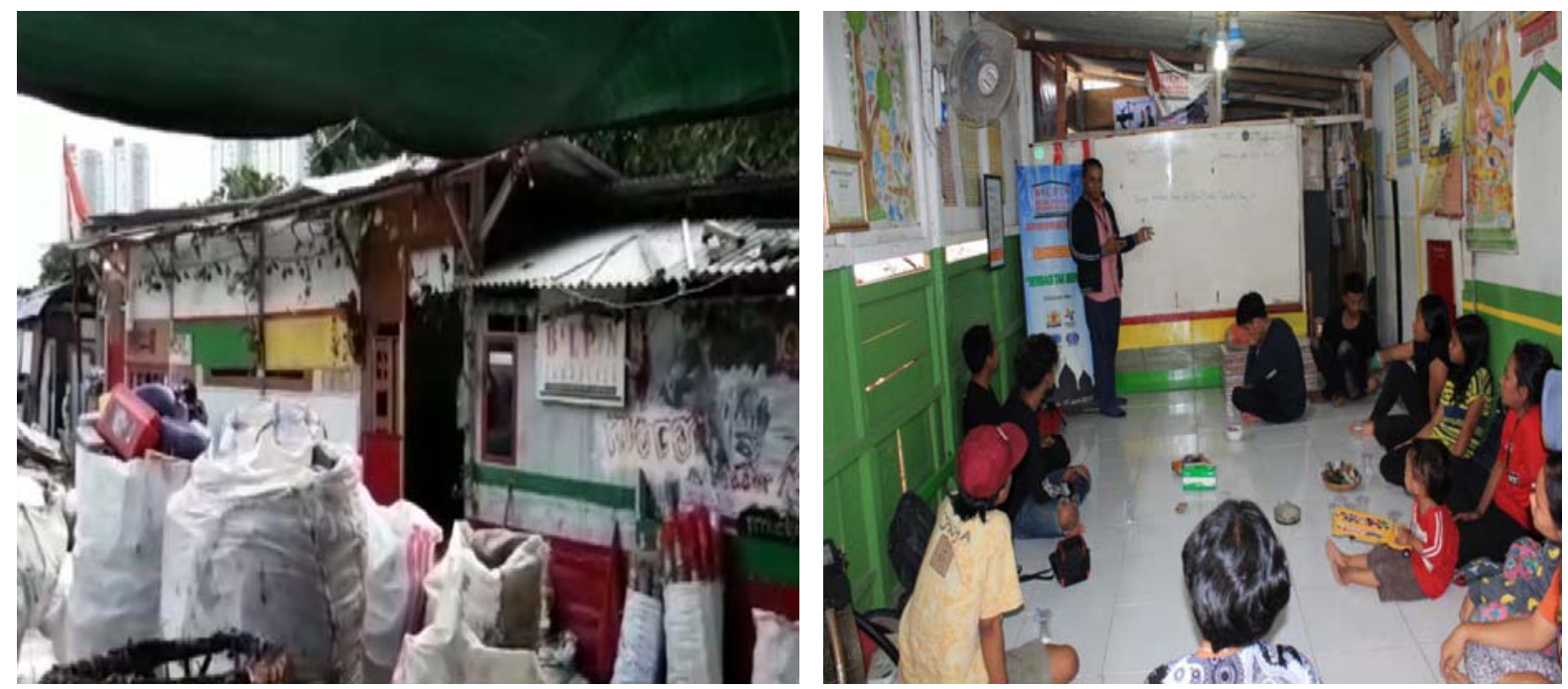

Picture 1. The learning facility and the neighbourhood situation of Bilpin Learning Group in Kampung Pemulung, Menteng Atas, Jakarta

Financial problem is the culprit of this social problem. Some of them must help their parents to earn for living by collecting trash or becoming street buskers. Another contributing factor is the lack of social and parental support for the children in the neighbourhood.

Bilpin essentially identified 3 major problems, (1) the students dropped out at three major level SD, SMP, SMA/SMK, (2) they lack motivation in terms of learning, and (3) the family financial problem is playing a vital part.

The writers and 3 college students from Universitas Mercu Buana carried out a Social Engagement Program or locally known as Program Kemitraan Masyarakat (PKM). This program is aimed to promote the students' learning motivation, especially among school dropouts. One of ways to address this issue is by developing multimedia-based learning. Students are assisted to use computer, create a simple application and create simple website, as well as to learn video editing and graphic designing. It's expected that the students are willing to go back to school to pursue their formal education, and hopefully developed entrepreneurial skills in multimedia industry.

\section{MULTIMEDIA-BASED LEARNING}

In a nutshell, multimedia-based learning is a learning approach that makes use the most of computer or computer software. Learners are assisted to use the computer software to combine texts, voice, picture, animation, audio and video, so that interaction and communication can be made better. Multimedia has also been adopted by game industry and website developers. [3].

The implementation of the program falls into several phases. Following table is the detailed explanation for each step. 
Table 3. The Implementation of Multimedia-Based Learning

\begin{tabular}{|c|c|c|}
\hline STEP & ACTIVITY & \begin{tabular}{|l|} 
DESCRIPTION \\
\end{tabular} \\
\hline 1 & Learning Module Creation & $\begin{array}{l}\text { Three modules have been developed, that is: } \\
\text { - } \quad \text { Basic Computer Usage } \\
\text { - } \quad \text { Basic Game Coding and Website Coding } \\
\text { - } \quad \text { Basic Camera Operation Techniques for TV } \\
\text { - } \quad \text { Basic Video Editing Techniques } \\
\end{array}$ \\
\hline 3 & $\begin{array}{l}\text { Training-Related Operational } \\
\text { Preparation }\end{array}$ & $\begin{array}{l}\text { The preparation includes the operational side of the training and } \\
\text { the announcement }\end{array}$ \\
\hline 4 & Field Coordination & \begin{tabular}{|l} 
Stakeholders involved: \\
- $\quad$ The Founder of Bilik Pintar, Teguh Suprobo, \\
- $\quad$ The Person in Charge in Bilpin, Kampung Pemulung, \\
- Social Engagement Unit (Universitas Mercu Buana Jakarta) \\
\end{tabular} \\
\hline 5 & $\begin{array}{l}\text { The Socialization of the } \\
\text { implementation program } \\
\text { (Science and Technology } \\
\text { Program) }\end{array}$ & $\begin{array}{l}\text { The socialization process takes two phases, namely: } \\
\text { - The initial non-formal socialization, this step is to build a good } \\
\text { rapport with the founder and the field operators of Bilpin. } \\
\text { - The second step is a formal discussion with the students in } \\
\text { Bilpin. }\end{array}$ \\
\hline 6 & $\begin{array}{l}\text { Basic Computer Operation } \\
\text { Training }\end{array}$ & $\begin{array}{l}\text { The following are the coverage area: } \\
\text { - Understanding Computer Hardware (CPU, Keyboard, Mouse, } \\
\text { Monitor) } \\
\text { - Understanding electrical cord to power the PC and } \\
\text { understanding shut-down buttons and procedures to turn off } \\
\text { the pc } \\
\text { - Understanding Mouse, Keyboard, USB } \\
\text { Operating MS Word and understanding document folder } \\
\text { management }\end{array}$ \\
\hline 7 & Basic Game Coding Training & $\begin{array}{ll}\text { It consists of: } \\
-\quad \text { Basic Game Coding } \\
-\quad \text { Installing Supporting Software } \\
-\quad \text { Creating MIDlet Project, File MIDlet, and Hello World } \\
-\quad \text { Creating a number guessing game } \\
-\quad \text { Creating a simple Pong game } \\
\end{array}$ \\
\hline 8 & $\begin{array}{l}\text { Basic Website Coding } \\
\text { Training }\end{array}$ & $\begin{array}{l}\text { This training covers the following area: } \\
\text { - } \quad \text { Introduction to HTML } \\
\text { - } \text { forderstanding HTML Document and its document standard } \\
\text { - } \quad \text { Executing Text Formatting, and listing in HTML document } \\
\text { Build a website with HTML tags }\end{array}$ \\
\hline 9 & $\begin{array}{l}\text { Basic TV Camera Operation } \\
\text { Training }\end{array}$ & $\begin{array}{ll}\text { The training covers: } \\
-\quad \text { TV camera and shooting technique (7 Shot Size) } \\
\text { - } \quad \text { Camera Movement Shot and Camera Angle Shot } \\
\text { - } \quad \text { Picture Sequence and continuity } \\
\text { - Interview and On-Cam techniques }\end{array}$ \\
\hline 10 & Basic Video Editing Training & $\begin{array}{l}\text { The module covers the following area: } \\
\text { - } \quad \text { Understanding Software Video Editing and Installing } \\
\text { Software Video Editing } \\
\text { - } \quad \text { Capturing and Cut to Cut Editing Technique } \\
\text { - Online Editing and Rendering/ Exporting }\end{array}$ \\
\hline 11 & Basic Graphic Design Training & $\begin{array}{l}\text { The module covers these areas: } \\
\text { - Understanding Graphic Design Software and elements of } \\
\text { layouts } \\
\text { - Combining functions, components and colors } \\
\text { - Creating picture/illustration/text }\end{array}$ \\
\hline
\end{tabular}




\section{RESULT AND DISCUSSION}

Ever since the coordination and training phases, the program has been enthusiastically welcomed by both operators of Bilpin and the students themselves. Students' enthusiasm and interest throughout the program are obviously observable. In fact, most of them know how to operate a computer, though mostly limited to playing games. They can access computer and internet through a nearby internet café. The learning approach being administered was basically staged from the early step to more technical ones.

Table 4. General Profile of Bilik Pintar Learning Facility (Bilpin)

\begin{tabular}{|l|l|l|}
\hline Unit Name & $:$ & Kelompok Belajar Bilip Pintar (Bilpin) \\
\hline Address & $:$ & $\begin{array}{l}\text { Kampung Gasong, Menteng Pulo, Kelurahan Menteng Atas, } \\
\text { Kecamatan Setia Budi, Jakarta Selatan }\end{array}$ \\
\hline Founder & $:$ & Teguh Suprobo \\
\hline Teachers/Tutors & $:$ & Teguh Suprobo, Ibu Asmonah, Ibu Mia, Pak Sunarto \\
\hline $\begin{array}{l}\text { Number of Registered } \\
\text { Students }\end{array}$ & $:$ & 74 students \\
\hline Number of Active Students & $:$ & 35 students \\
\hline $\begin{array}{l}\text { General Training } \\
\text { Impressions }\end{array}$ & $:$ & Students are highly enthusiastic. \\
\hline
\end{tabular}

There are 3 locations for the learning program, that is (1) the learning facility equipped with rented multimedia tools, (2) a rented graphic design laboratory, and (3) a rented editing laboratory. The training instructors are lecturers of Universitas Mercu Buana, college students of Universitas Mercu Buana, as well as laboratory instructors for graphic design and editing lab sessions. Learning facilities and instructors are to maximize the learning process, so that students can grasp the material optimally.
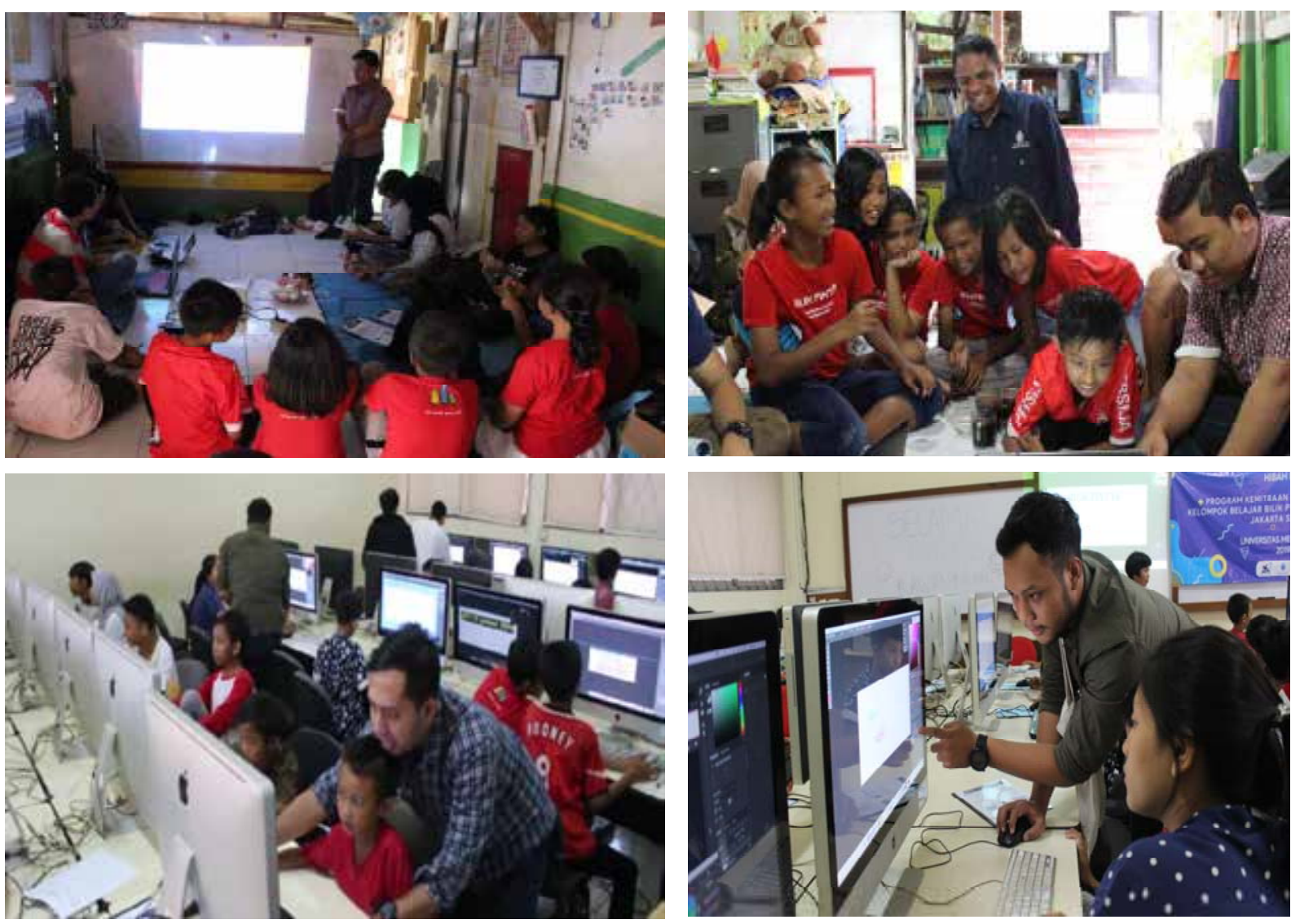

Picture 2. Learning Process in Bilpin Learning Facility \& in Computer Laboratory 
Having provided 5 learning sessions using the multimedia approach, a questionnaire was administered to measure students' enthusiasm towards the program. The following table and diagram illustrate 35 students' response. $60 \%$ of them (around 21 students) said they feel 'highly enthusiastic' to the program meaning that they responded well to the program. $8,6 \%$ seemed to be indifferent and believe that they'd rather do something that yield money. They have pragmatic view on the time they have. $20 \%$ admitted that they just followed whatever given to them, and $8,6 \%$ barely interested in the program or learning materials.

Table 5. Students' Enthusiasm Throughout the Training Process

\begin{tabular}{|l|c|c|}
\hline Students' Responses & Number & Percentage \\
\hline Highly Enthusiastic & 21 students & $60 \%$ \\
\hline Barely Enthusiastic & 4 students & $11,4 \%$ \\
\hline Just Playing Around & 7 students & $20 \%$ \\
\hline Indifferent / Choose to Work & 3 students & $8,6 \%$ \\
\hline \multicolumn{1}{|c|}{ Total } & 35 students & $100 \%$ \\
\hline
\end{tabular}

\section{STUDENTS' RESPONSES}

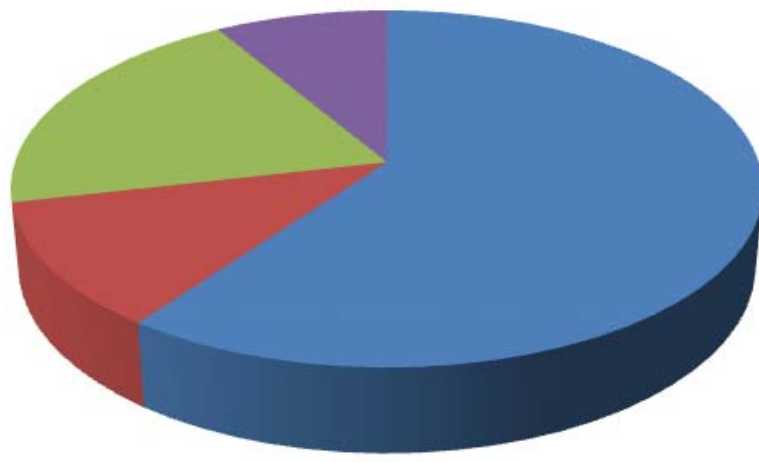

- Highly Enthusiastic

Barely Enthusiastic

- Just Playing Around

Indifferent / Choose to Work

Picture 3. The Distribution of Students' Learning Enthusiasm

We found out an interesting phenomenon. The data showed that $91 \%$ or 32 students acknowledged that they have gained new knowledge through the program. They think that it's more beneficial than using computer in an internet café, while 3 of them didn't answer the question. Those who perceived that they have gained new knowledge stated that they will stay in the program and are reconsidering going back to school.

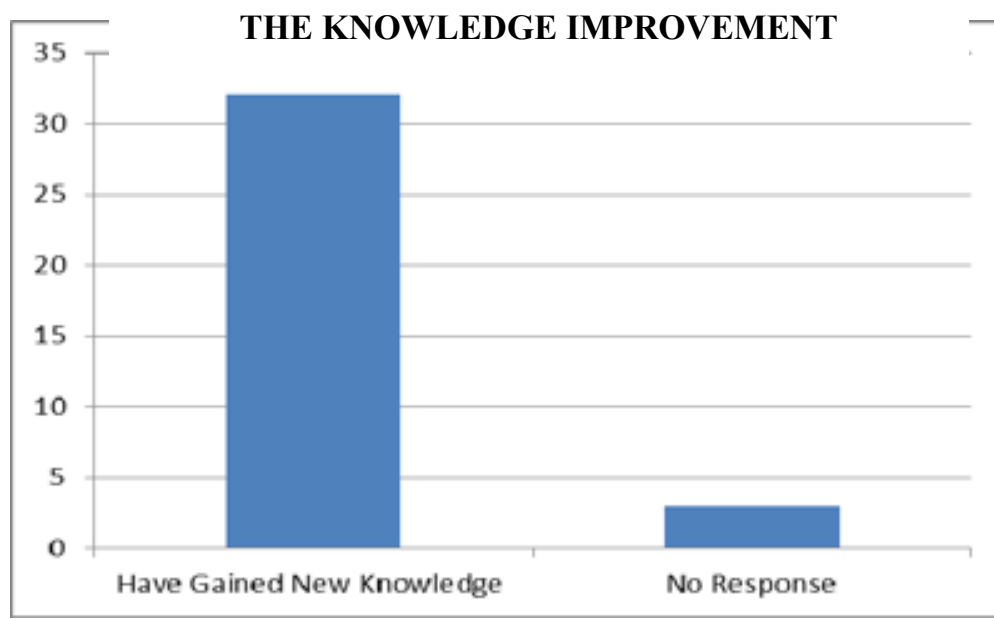

Picture 4. The Distribution of Students' Response if They Have Gained New Knowledge

Besides, there's a surprising result. 4 students who previously dropped out of school decided to go back to school. Meanwhile 12 students are reconsidering going back to school, only one student insists not to go back 
to school. The rest of the participants, 18 students who are apparently non dropouts mentioned that they are convinced to pursue their education until college.

Table 6. The Improvement of Students' Learning Motivation

\begin{tabular}{|l|l|l|c|}
\hline No & Their Attitudes towards school & Number & Percentage \\
\hline 1 & Decided go back to school & 4 students & $11,4 \%$ \\
\hline 2 & Reconsider to go back to school & 12 students & $34,3 \%$ \\
\hline 3 & Will not go back to school & 1 student & $2,8 \%$ \\
\hline 4 & Stay in school until college & 18 students & $51,4 \%$ \\
\hline & Total & 35 students & $100 \%$ \\
\hline
\end{tabular}

\section{Students’ Attitude Towards School}

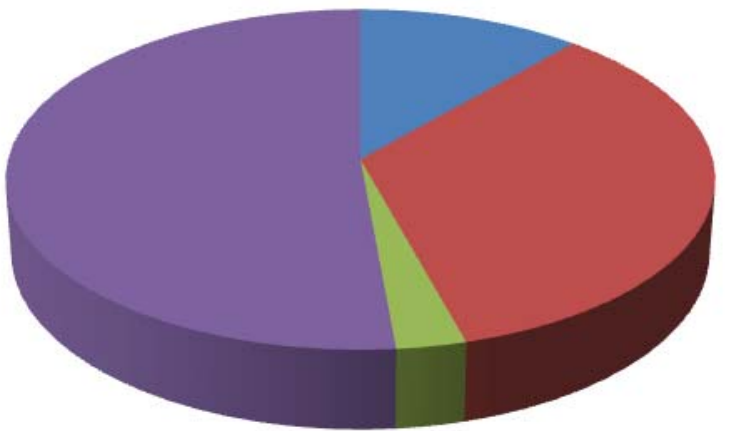

Decided go back to school

Reconsider to go back to school

Will not go back to school

Stay in school until college

Picture 5. The distribution of the students' perspective in terms of their learning attitudes

The above chart shows that's only $2 \%$ of the students remains resistant, meaning that the attitude towards school didn't change. On the other hand, 98\% participants choose to continue their education in school as high as possible Furthermore, 11,4\% of them decided to go back to school right away, and 51,4\% of them feeling more optimistic to finish their education.

Another goal of this program is to rebrand the learning facility. The founder, Teguh Suprobo opted to rebrand Bilpin into YoiSkul which is now under Yayasan Obama Indonesia (YOI). Yoi Skul aims to invite and persuade students dropouts who are mostly street buskers, trash scavengers to go back to schools. YOI is the acronym of Yayasan Obama Indonesia. Obama is the name of the founder's son who was named after the former president of the USA. The name Obama is used to inspire the endeavour as well as a form of gratitude for the founder's son birth in 2013.
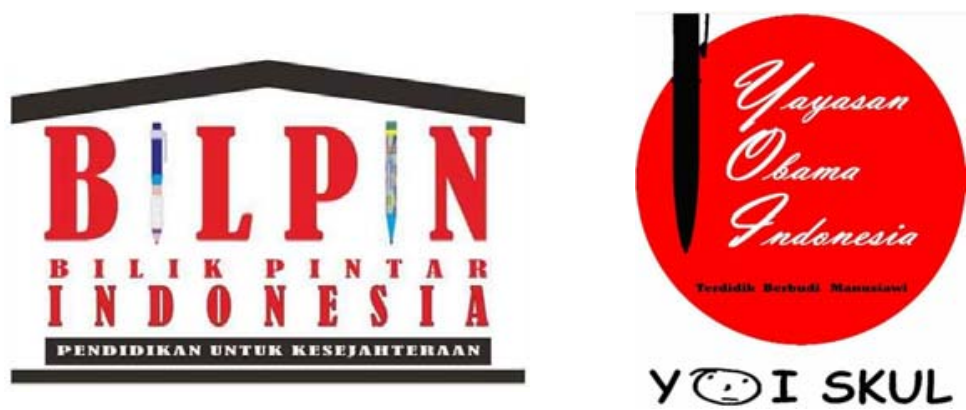

Picture 4.6. The Logo of Bilik Pintar and That Of YOI SKUL 


\section{CONCLUSION}

Multimedia-based learning approach has been proven effective to retain and promote students' attitude and enthusiasm towards learning and school in general. The learning process was given to 35 underprivileged students registered in Bilpin.

$95 \%$ of the students shows more positive attitude towards school and more profound interest to learning. $11,4 \%$ decided to go back to school. $34,5 \%$ of them highly reconsidered going back to school after the program. Meanwhile, $51,4 \%$ of the students have become more certain to finish their education and learn more about multimedia.

However, we must acknowledge that this multimedia-based learning has only touched the surface, meaning that this program only gives some new experience and fresh exposure for the students. It's necessary to maintain and improve their skills in a long-term and sustainable training. It's hoped through multimedia, they can develop technical and entrepreneurial skills to solve their financial difficulties that most of the family is facing.

\section{REFERENCES}

[1] BPS DKI Jakarta. 2018. Iktisar Data Pendidikan Tahun 2016/2017. Jakarta: Badan Pusat Statistik Provinsi DKI.

[2] BPS DKI Jakarta, (2017). Prosentase Penduduk Miskin DKI Jakarta September 2017. Jakarta: Badan Pusat Statistik Provinsi DKI.

[3] Hartono, Jogiyanto. (2000). Pengenalan Komputer: Dasar Ilmu Komputer, Pemrograman, Sistem Informasi, dan Intelegensi Buatan. Yogyakarta: Penerbit Andi Publisher.

[4] Hendratman, Hendri. (2017). The Magic of Adobe Premiere Pro. Jakarta: Penerbit Gramedia.

[5] Kusrianto, Adi. (2007). Pengantar Desain Komunikasi Visual. Yogyakarta: CV Andi Offset.

[6] Nugroho, Andi Taru. (2013). Cara Mudah Membuat Game Android. Yogyakarta : Penerbit Andi Publisher.

[7] Nugroho, Andi Taru. (2012). Pemrograman Game Berbasis Web Menggunakan JavaScript + HTML 5. Yogyakarta : Penerbit Andi Publisher.

[8] Wulan, Ayoda. (2016). 14 Hari Langsung Mulai Jadi Pengusaha. Jakarta: Penerbit Kompas Gramedia. 